Pieistocene origin, while that from Engis, described by Schmerling in 1833 , is evidently much more recent. The origin of the well-known Neanderthal calvaria has always been doubtful, but its extraordinary heavy brows and low forehead gave it an interest at the time of its discovery, which is not lessened now that very similar skulls have been found under better authenticated conditions.

The Moulin Quignon jaw, which created so much discussion for a few years after its its discovery in 1863 , has long since been put aside as lacking authenticity. But the jaw found by $\mathrm{M}$. Dupont in the Naulette cave is accepted as that of a human being that lived with the mammoth. The human bones from the caves of Aurinac, Cromagnon, Frontal, Mentone, and some others were shown by Prof. Boyd Dawkins to be of neolithic age. The skeleton found at a depth of thirty-two feet at Tilbury Docks in 1883 was thought by Sir R. Owen to be of palrolithic age, but Mr. T. V. Holmes has shown that those gravels are of comparatively modern origin, and could not be older than neolithic.

A fresh impetus was given to the study of palæolithic man by the memoir of MM. Fraipont and Lohest, who in 1887 gave an account of two remarkable skeletons found at Spy, in the province of Namur, Belgium. These skeletons are accepted as of the same age as the extinct mammals, with the bones of which they were found associated. The skulls are of a low type, and one of them especially makes a very close approach to that from the Neanderthal, not only in the general form, but also in the great development of the brow ridges and the lowness of the forehead.

A single tooth from Pont Newydd cave, St. Asaph ; a piece of a skull from the brick-earth of Bury St. Edmunds, and parts of a skeleton from the high terrace-gravel of Galley Hill, Northfleet, are believed to be the only well-authenticated instances of palæolithic human remains yet found in Britain; and it is only the skeleton last named that is sufficiently well-preserved to give any idea of the form of the skull or limb-bones. The Galley Hill skull is very long and narrow, the brow ridges are strongly developed and the forehead is low, but not so depressed as in the Neanderthal calvaria. Although it may not be correct to include the Java Pithecanthropus in the genus Homo, yet as it holds an intermediate position between the lowest type of human skull, - the Neanderthal-and that of certain apes, it cannot be neglected when considering the early progenitors of man and its position in the geological series at the beginning of the Pleistocene, if not in the Pliocene, is precisely the place where such an ancestor would be expected to appear.

Although the greater number of the human remains supposed to be of palrolithic age are now known to be of more recent origin or are not well substantiated, yet there are a few which nay be accepted as in all probability representatives of the men who made the palæolithic implements. In the latter category may be placed the skeletons from Spy and that from Galley Hill, as well as the jaw from Naulette and the piece of skull from Bury St. Edmunds. The Eguisheim skull and a few other remains found on the continent of Europe should perhaps be included with these. The famous calvaria from Neanderthal and Canstadt are among the remains of uncertain origin, but, on account of their resemblance to the Spy skulls, are sup. posed to be of the same age, and to belong to the same race.

If we accept the Spy, and other skeletons, as the remains of the men who made the palæolithic implements, what do they tell us of the mental and physical condition of those early progenitors of mankind? As a gauge of intellectual capacity, we have to confess that their skulls tell us far less than do the relics of their handiwork.

Prof. Huxley's dictum regarding the Spy men was that "the anatomical characters of their skeletons bear out conclusions which are not flattering to the appearance of the owners." They were short and powerful, but must have walked with a bend at the knees. Their skulls were depressed, with strong brow ridges and lower jaws of brutal depth. The Neanderthal skull has been said by the same authority to be the most apelike of human crania yet discovered. At the same time it is highly probable that these palæolithic men were not less intelligent than some of the savage races living at the present day, for their brain capacity seems to have been as great as that of average Hottentots and Polynesians ; and with an equal volume of brain we may presume there was an equal intellectual power. Moreover, men of no mean intellectual capacity are known to have possessed skulls of the Neanderthal type.
It may be doubted whether we are right in regarding the Neanderthal type of skull as typical of the palæolithic race, for other skulls referable to this period are less marked in character, and appear to indicate a greater range of form within the race than has usually been supposed. At present we have too few examples to allow of any definite deductions being made; but what we do know, points to the palæo!ithic race having had long skulls (dolichocephalic), in which particular they approach the neolithic race ; but differ from them in the greater development of their brow ridges, in their lower and more receding foreheads, and in their shorter stature.

That palæolithic man possessed considerable mechanical skill, is shown by the well-fashioned flint implements that have been found ; and the striking outlines of animals and men incised by him on pieces of ivory and bone, as well as the clever carvings in similar material, is evidence of no little artistic ability. And further, if we bear in mind how little of his work has been preserved to us, and how much that was perishable must have entirely disappeared, we shall be inclined to credit our palæolithic ancestors with a somewhat higher social status than we have usually supposed them to have enjoyed.

\section{ALCOHOL IN RELATION TO MICROBIAL DISEASES}

THE effect of alcohol on the artificial production of immunity in animals in regard to rabies, tetanus, and anthrax has been recently studied by Dr. Deléarde. It has been frequently observed that persons addicted to alcohol suffer, as a rule, far more severely from the effects of microbial infections than normal individuals, and not long ago, in 1896 , Abbot, of Philadelphia, showed that pathogenic bacteria, incapable of killing healthy animals, were able to produce fatal results in animals intoxicated with alcohol. This was found to be the case with the $B$. coli communis, the staphylococcus, and the streptococcus. Deléarde has turned his attention to the effect produced by alcohol on the artificial prevention of disease in animals; and, considering the great importance of the subject, it is to be regretted that his conclusions are drawn from so few experiments. It appears that a rabbit vaccinated against rabies, and then given considerable quantities of alcohol (introduced into the esophagus by means of a tube) for several weeks, and subsequently inoculated with fresh rabid virus, did not succumb to rabies, whilst another rabbit treated similarly, only omitting the doses of alcohol, died of rabies. In this case the alcohol had apparently preserved the animal's immunity to rabies. On the other hand, a rabbit dosed with alcohol during the course of the anti-rabic inoculation, obtained absolutely no immunity from rabies; whilst a rabbit, first of all intoxicated and then vaccinated, acquired immunity to rabies as long as the supply of alcohol was stopped as soon as the vaccinations were commenced. In the case of tetanus, however, if the anti-tetanic inoculations were succeeded by the administration of alcohol, the animal lost all its artificially acquired immunity to the disease, and invariably succumbed to tetanus infection; again, if treated with alcohol during the vaccinations, it only acquired immunity to tetanus with difficulty, and if first of all intoxicated and then vaccinated, the animal obtained immunity as long as the supply of alcohol ceased when the vaccinations began. As regards anthrax, it is almost impossible, it appears, to protect animals from this disease if they are treated with alcohol during the vaccination period. On the other hand, animals first intoxicated and then vaccinated can acquire immunity providing, as in the other cases mentioned above, the alcohol is stopped as soon as the vaccinations are commenced, but they suffer considerably more during the process than animals which have received no alcohol. The experimental results obtained with rabies bear out the observations which have been made with regard to intemperate persons and the antirabic treatment in various Pasteur Institutes, and a very striking instance of the ineffectuality of the treatment in such a case was recorded only this year. An habitual drunkard was bitten by a mad dog, as was also a child by the same dog ; both underwent precisely the same anti-rabic treatment. The man during the whole time continued to drink to excess, and subsequently died of rabies, whilst the child remained perfectly well. In the case of the administration of antitoxins it would appear, therefore, highly desirable that at least during the vaccinations alcohol should be prohibited.

$$
\text { NO. } 1476 \text {, vOL. 57] }
$$

